\title{
Erratum: Induced pluripotent stem cell-derived neuronal cells from a sporadic Alzheimer's disease donor as a model for investigating AD-associated gene regulatory networks
}

Amir M Hossini ${ }^{1+}$, Matthias Megges ${ }^{2,5,6+}$, Alessandro Prigione ${ }^{2,8}$, Bjoern Lichtner $^{2}$, Mohammad R Toliat ${ }^{3}$, Wasco Wruck ${ }^{5}$, Friederike Schröter ${ }^{5}$, Peter Nuernberg ${ }^{3}$, Hartmut Kroll ${ }^{4}$, Eugenia Makrantonaki ${ }^{1,7}$, Christos C Zouboulis ${ }^{1}$ and James Adjaye $2,5^{*}$

\section{Erratum to:}

BMC Genomics 2015, 16:84 doi:10.1186/s12864-0151262-5.

Following publication of this article it was brought to our attention that the name of author; Christos C. Zouboulis was incorrectly spelt as 'Zoubouliss'. Eugenia Makrantonaki, Christos Zouboulis and James Adjaye are equal senior authors.

\section{Authors' information \\ Eugenia Makrantonaki, Christos C. Zouboulis and James Adjaye senior authors.}

\begin{abstract}
Author details
'Departments of Dermatology, Venereology, Allergology and Immunology, Dessau Medical Center, 06847 Dessau, Germany. ${ }^{2}$ Department of Vertebrate Genomics, Molecular Embryology and Aging Group, Max Planck Institute for Molecular Genetics, 14195 Berlin, Germany. ${ }^{3}$ Cologne Center for Genomics (CCG), Institute for Genetics, University of Cologne, 50931 Cologne, Germany. ${ }^{4}$ Institute for Transfusion Medicine Dessau, Red Cross Blood Transfusion Service NSTOB, 06847 Dessau, Germany. ${ }^{5}$ Institute for Stem Cell Research and Regenerative Medicine, Heinrich Heine University Duesseldorf, Moorenstr. 5, 40225 Duesseldorf, Germany. ${ }^{6}$ Department of Biology, Chemistry and Pharmacy, Institute of Chemistry and Biochemistry, Freie Universität Berlin, Thielallee 63, 14195 Berlin, Germany. ${ }^{7}$ Department of Geriatric Medicine, Geriatrics Research Group, Charité Universitätsmedizin Berlin, Reinickendorfer Str. 61, 13447 Berlin, Germany. ${ }^{8}$ Current address: Max Delbrueck Center for Molecular Medicine (MDC), Robert Roessle Str. 10, D-13125 Berlin, Germany.
\end{abstract}

Received: 14 April 2015 Accepted: 14 April 2015

Published online: 06 June 2015

\footnotetext{
* Correspondence: james.adjaye@med.uni-duesseldorf.de

'Equal contributors

${ }^{2}$ Department of Vertebrate Genomics, Molecular Embryology and Aging Group, Max Planck Institute for Molecular Genetics, 14195 Berlin, Germany ${ }^{5}$ Institute for Stem Cell Research and Regenerative Medicine, Heinrich Heine University Duesseldorf, Moorenstr. 5, 40225 Duesseldorf, Germany Full list of author information is available at the end of the article
}

\section{Submit your next manuscript to BioMed Central and take full advantage of:}

- Convenient online submission

- Thorough peer review

- No space constraints or color figure charges

- Immediate publication on acceptance

- Inclusion in PubMed, CAS, Scopus and Google Scholar

- Research which is freely available for redistribution

Submit your manuscript at www.biomedcentral.com/submit (c) 2015 Hossini et al.; licensee BioMed Central. This is an Open Access article distributed under the terms of the Creative Commons Attribution License (http://creativecommons.org/licenses/by/4.0) which permits unrestricted use, distribution, and reproduction in any medium, provided the original work is properly credited. The Creative Commons Public Domain Dedication waiver (http://creativecommons.org/publicdomain/zero/1.0/) applies to the data made available in this article, unless otherwise stated. 